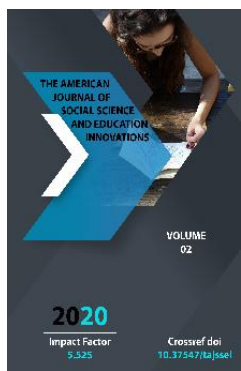

\title{
Religious Policy In Turkestan In The 20s Of The Xx Century
}

\author{
Isakova Feruza Rakhmanovna \\ Lecturer At The Department Of World History Of Andijan State University, Andijan Region, \\ Republic Of Uzbekistan
}

Journal Website:

http://usajournalshub.c

om/index,php/tajssei

Copyright: Original

content from this work

may be used under the

terms of the creative

commons attributes

4.0 licence.

\section{ABSTRACT}

This article reveals the policy of the Soviet government in relation to Islam in the 1920 of the XX century. This policy was initially dual in nature, that is, on the one hand, the Bolsheviks established strict control in the Muslim regions of Russia, on the other hand, until a certain time Muslims were allowed to follow their traditions and customary norms of life. However, in the second half of the 20 after strengthening its position, the Soviet government began to implement the policy of atheism everywhere in order to finally put an end to religion.

\section{KEYWORDS}

Soviet power, decree, Islam, religion, politics, clergy, waqfs, legal proceedings, Sharia, adat, education, atheism, repression.

\section{INTRODUCTION}

The violent imposition of Soviet power was accompanied in Turkestan with the creation of political and ideological structures. They were aimed, first of all, at ousting the religious worldview incompatible with the Bolshevik ideology. Already in the 1920s, large-scale religious persecutions unfolded, expressed in measures to eliminate waqfs, in the closure of confessional schools, in the prohibition of the courts of Qazis, in the persecution of clergy.

\section{METHODS}

The revolutionary events of 1917 laid the foundation for qualitative changes in the life of Muslims in Russia. At first, the Soviet government adhered to certain attitudes towards Islam, which were formed during the era of the empire. Her policy was initially ambivalent. On the one hand, the authorities established strict control in the Muslim 
regions of Russia, on the other, Muslims were allowed to follow their usual norms of life.

\section{RESULTS AND DISCUSSIONS}

In the very first years of Soviet power, practical measures began to be implemented to introduce the so-called secularization of all aspects of the life of the population of Central Asia. In this regard, concrete steps were taken to regulate relations between the state and religion. The foundation of these relations was laid on November 24, 1917, when the Council of People's Commissars' Appeal To All Working Muslims of Russia and the East was published, which stated that the Soviet government declares the beliefs and customs of Muslims, their national and cultural institutions, free and inviolable [1]. On January 20, 1918, the Council of People's Commissars of the RSFSR, and then on November 20 of the same year, the Council of People's Commissars of the TASSR adopted decrees on the separation of church from state and school from church, in which religious associations were denied the right to be legal entities. "Every citizen, - stated in article 3 of the decree, - can profess any religion or not profess any". The execution of religious rites was allowed, according to the decree, insofar as they did not violate public order and were not accompanied by encroachments on the rights of citizens of the Soviet Republic [2]. In Turkestan, the solution of all issues related to the religious activity of Muslims was transferred to the People's Commissariat for Nationalities - the People's Commissariat for Nationalities. Under him, a vakuf committee was established, whose task was to manage the property previously owned by Muslim organizations.
Despite the fact that the adopted decrees applied to all religions, in the first years of Soviet power they were directed mainly against Orthodoxy. The religious policy of the new government in relation to Muslims was much milder, especially since "there were many Muslims in the local administration who not only did not show anti-religious zeal, but, on the contrary, showed respect for tradition whenever possible" [3]. In addition, against the background of the enormous difficulties associated with the insurgency, it was extremely dangerous for the new government to arouse the discontent of huge sections of the Muslim population. In a sense, we can say that the Soviet government, to some extent, inherited a very cautious policy towards Islam from its predecessor, the colonial administration of Tsarist Russia. And if we take into account the fact that a more or less conscious part of the Muslim population hoped for positive changes on the part of the Bolsheviks, then the measures taken in the first years of Soviet power in relation to religion turned out to be strategically correct and attracted a significant part of the local population to its side. This is supported by the fact that between 1917 and 1920 many politically active Muslims joined the ranks of the Communist Party. According to the American researcher $A$. Bennigsen, this was due to reasons of a purely practical nature, namely, "the political incompetence of the commanders-in-chief of the white armies and their complete lack of understanding of the national question and the requirements of Muslims, the personal intervention of Stalin, then People's Commissar for Nationalities, who managed to attract to their side by the main leaders of the left wing of the national movement, Lenin's vague and ambiguous 
promise of self-determination for Muslims in the April Theses, the hope that the October Revolution is just the first step towards the liberation of the entire Muslim world ... that the revolution of 1917 year will be in Muslim territories a continuation of the reform movement of the XIX century "[4]. In other words, on the part of Muslim leaders, joining the ranks of the Communist Party was also a kind of tactical move. This did not at all indicate that they unconditionally accepted the Bolshevik doctrine.

A significant part of the clergy welcomed the idea of common social attitudes of communism and Islam, and even put forward the slogan "For Soviet Power and Sharia." In January 1918, the Tashkent organization "Ulema" made an appeal to the Russian socialists. This appeal clearly demonstrated the readiness of the most progressive part of the local clergy to cooperate with the Bolsheviks, and the basis of this cooperation was precisely the hatred of the common enemy - imperialism: "Islam and socialism," the address said, "what an incredible, at first glance, combination! And meanwhile, if you look closely at their essence, then how much they have in common and kindred: ... both of them are the same enemies of imperialism, equally do not recognize the idea of nationalism and declare a merciless war against the oppression of capital "[5].

In order to win over the local population, the Bolsheviks took a number of appropriate steps. In June 1919, the 3rd Congress of the CPT adopted a resolution "On the policy of the RCP (b) in the Turkestan village", which stated: "Organize party cells in villages and kishlaks according to the class principle, temporarily allowing reduced requirements for party consciousness" [6]. This meant that believers could be admitted to the party, since there were no atheists among the rural population of Turkestan and could not be due to the established way of life. Ultimately, the implementation of this resolution was supposed to strengthen the position of the Communist Party in the countryside and artificially intensify the process of class stratification there. Moreover, in the radiogram of the Central Committee of the RCP (b) dated July 10, 1919, the Krai Committee of the Communist Party of Tajikistan spoke of the need for broad proportional involvement of "the local population in state activities", and "without obligatory membership in the party" [7]. This presupposed the possibility of participation in the work of the state apparatus of believers, since party membership in the city was due to the mandatory renunciation of religion.

Considering that in the first years of Soviet power, the positions of the clergy and their authority among the local population were still very high, the Bolsheviks used this factor in their own interests. In the resolution of the $\checkmark$ Congress of the CPT (September 1920) "On the tasks of the Communist Party in Turkestan" it was said: "Since there is a progressive part among the ulam, it is mainly to recognize the possible technical use of it in Soviet institutions" [8].

During this period, even mosques began to be used to propagate revolutionary ideas, especially during Friday prayers and various religious holidays, which, of course, was impossible without the participation of representatives of the clergy.

Be that as it may, even despite the disagreements with the Bolsheviks on many 
issues, already in the first years of Soviet power, many Muslims were admitted to the ranks of the Communist Party. These Muslim communists played a significant role in the life of the republic during the first ten years. "Despite the fact that their ideas, theories and political programs often contradicted the Bolsheviks," writes A. Bennigsen, "the Bolsheviks were usually forced to endure them for reasons of a strategic nature, while trying to neutralize their influence. And only after 1928, Stalin had the opportunity to completely eliminate them "[9].

An attempt by the new government to change the judicial system based on the Sharia court, as well as the confiscation of waqf lands and the elimination of maktabs, met with great resistance from the local population. All these measures began to be carried out in 1919, despite the instruction of the People's Commissariat of the RSFSR to prohibit the use of any reprisals against mullahs for teaching the dogmas of the Muslim doctrine in mosques, at home, as well as to prohibit the closure of theological schools maintained at the expense of voluntary donations from individuals [10]. A sharp transition to a secular education system in Central Asia was impossible, since in the minds of the local population there was a prejudice that teaching in secular schools meant rejection of Islam. In addition, the Soviet government faced a number of other difficulties, such as the impossibility of teaching girls and boys together, the lack of funds to build new schools, and a weak material and educational base. The same negative reaction was caused by the attempt to abolish the courts based on Sharia and adat and enjoy great authority among the local population. In the period 1919-1920. Waqf lands and other property were confiscated from mosques, and mosques were often attacked while reading a prayer. The Bolsheviks did not want to take into account the fact that "the bulk of the population - Uzbeks, Tajiks and other nationalities of Central Asia - professed Islam, which differs from other religions in that it provides more than in other religions in terms of the daily routine of human life" [ eleven].

The failure of the measures carried out by the Soviet government in relation to religion prompted the Bolsheviks to pursue a more flexible policy towards Islam in Central Asia. For example, unlike other regions where the application of the laws of the overthrown governments was prohibited, the "Regulations on the Unified People's Court of the RSFSR", enacted (with amendments) on the territory of the TASSR in 1919, provided for such a provision when "in the absence of an appropriate decree, the people's the courts were to be guided by socialist sense of justice and applicable law (Sharia, adat) "[12]. Sharia and adat continued to be the main source of civil law.

On May 6, 1922, the Turkish Central Executive Committee issued a decree, according to which the Kazi courts were returned to the practice of legal proceedings. On June 15, 1922, it was approved at a meeting of the Executive Bureau of the Central Committee of the CPT. Be that as it may, "the Sharia courts, which decided cases in such a way as not to enter into obvious contradictions with Soviet legislation, contributed to the maintenance of social and political stability in the country" [13].

The softening of the policy of the Soviet government was observed in relation to waqf property. In August 1921, the 10th Congress of 
Soviets of the TASSR divided waqfs into 2 categories: religious (belonging to mosques, mazars) and cultural and educational (belonging to madrasahs and maktabs). Waqfs of the first category were not subject to confiscation, as for waqfs of the second category, they were subject to socialist land management (depending on the wishes of the population) or had to be transferred to the People's Commissariat of Education, i.e. were actually nationalized. On June 20, 1922, the Turkish Central Executive Committee adopted a decree "On management of waqf property", according to which all religious waqfs were returned to their owners, but the establishment of new waqfs was prohibited [14].

Taking into account the mentality of the local population, in January 1921, Friday was declared a day off in the Turkic Republic, regardless of whether a person worked or studied in a Soviet or private institution. In a number of places, the authorities renovated and repaired mosques. [15]

This tolerant policy of the Soviet government towards Islam in Central Asia continued until 1923. However, here it should be stipulated that in 1923-1925. a kind of turning point came, first of all, in relation to Muslims of Russia proper. In Central Asia, the Bolsheviks continued to approach religious issues with extreme caution. First, the attitude of the new government to religion determined the attitude of believers towards it. Considering the fact that it was a phenomenon that pervaded all aspects of life and everyday life of the population, then such a policy on the part of the Bolsheviks was fully justified. Secondly, the rebel movement, which bore a pronounced anti-Bolshevik character, did not stop in the region. The main stake in this movement was made on the high level of religiosity of the population, which was very sympathetic, and often openly supported the "troops of Islam." However, the split that began in the rebel army led in 1924 to crushing blows from the Bolshevik army. Scattered detachments of fighters for the faith were often engaged in robbery and robbery of the local population, and this played into the hands of the Bolsheviks in order to attract the local population to their side.

The Bolsheviks' attraction of part of the clergy to their side was also of great importance in the implementation of land and water reforms in 1921-1924. and 1925-1927. During the first years of Soviet power, the Uzbek kishlak stably maintained its internal social relations. Its population, almost $100 \%$ composed of Muslims, has not changed either its religious beliefs or traditional communal relations, which were based on ancient mutual assistance and mutual assistance. All this guaranteed the survival of the members of the rural community in the most extreme conditions and conditioned the relaxation of social tension in the village, despite the existence of property inequality in it. To the general surprise of Soviet officials from the Center, the Bai estates did not burn in the Uzbek village, and the dekhkans did not seize not only the Bai lands, but did not even try to plow up the vacant lands left by the owners for any reason.

Land and water reforms were supposed to liquidate large Bai farms, confiscate their land, livestock and implements, from large labor farms with land in excess of the labor standard, take these surpluses and distribute them to landless and land-poor dekhkans. In 
order not to cause an explosion of indignation from the owners, who will be confiscated from their land, the Soviet government called for help from the Muslim clergy and received a "fatwa" from them. spiritual sanction. The spiritual mentors appealed to the population of the villages with an explanation that the free transfer of land into the hands of the poor is a charitable cause, and that the land reform of the Soviet regime does not contradict Sharia. They urged them to voluntarily, in the name of the Muslim brotherhood, give up their surplus land in favor of poor brothers.

This appeal of the Muslim clergy has yielded positive results. On the whole, the land reform proceeded calmly, although, of course, there were cases of both open and hidden resistance from those from whom the land was taken away.

The policy of the Soviet government with regard to public education in the first years after its establishment was also very flexible. The Bolsheviks decided to involve in its implementation the most progressive part of the clergy - the Jadids. The essence of this policy was to reform existing denominational schools. This process was headed by Munavvar-kori Abdurashidkhanov. Educational institutions that tried to resist reforms were closed or deprived of waqf property [16]. During this period, the official authorities allowed the functioning of maktabs and madrasahs.

In the same period, the Spiritual Administration (Mahkama-i Sharia) was created in Tashkent. It was headed by famous figures of Islam. His department, along with others, included departments that regulated the management of religious educational institutions. They also influenced the oldfashioned maktabs. Various courses were even organized for the teachers of these schools, and their attendance was compulsory. Gradually, by the mid-20s, the policy of the new government in relation to education began to tighten. In the decree of the Turkish Central Executive Committee No. 5 of January 18, 1925, it was said that it was necessary "to register all the old-school schools. Their maintenance should be attributed entirely to income from waqf assets, gradually including them in the network of public schools. All teachers of oldmethod schools are obliged to register with the department of public education and work only under its supervision "[17]. In December of the same year, a resolution of the Tashkent Old City Executive Committee "On the reform of old-method schools, madrasah and korikhona" was issued. According to this decree, the work of schools, madrasahs, korikhona was prohibited without the official permission of the People's Commissariat for Education. Anyone wishing to have such schools had to apply before May 1, 1926 to the Department of Public Education. All permits issued before January 1, 1925 were considered invalid. Persons who violated this regulation were fined 300 rubles or sent to one year of forced labor, schools were closed, and buildings and property were confiscated and transferred to the waqf department [18].

However, according to the secretary of the Central Committee of the Communist Party of Uzbekistan Akmal Ikramov, the loyal policy of the party and the Soviet state in relation to the religious organizations and beliefs of the local population of Central Asia, pursued in the early and mid-1920s, was not a concession, but only the tactics of the party [ nineteen]. 
By the end of the 1920s, it began to change, and the attitude towards religion was becoming more and more harsh. The release of religious literature is sharply reduced, the Muslim magazines Islam and Dianat are closed, the confiscation of religious buildings from religious communities begins, a significant part of which turns into schools, clubs, and sometimes into warehouses, hostility towards the Muslim clergy is growing. In the Resolution of the VI Plenum of the Central Committee of the CP (b) Uz in June 1927 "On Muslim clergy and school" it was written: "Islam, like other religions, is a great obstacle to the development of culture, the development and strengthening of the ideas of the proletariat and the construction of socialism." Therefore, the plenum set the task of intensifying the struggle against the clergy, "especially concentrating fire against the most dangerous, so-called progressive part of the clergy" [20].

\section{CONCLUSION}

Thus, the policy of the Soviet government in relation to religion until the end of the $20 \mathrm{~s}$. was twofold. On the one hand, it was aimed at the formation of an atheistic worldview, the basis of which was the communist ideology. However, the new government could not fail to take into account the deep religiosity of the people, which could not be eradicated by any extreme measures in the shortest possible time. Therefore, on the other hand, this policy was very cautious and to some extent tolerant. But when, at the end of the 1920s, the positions of the Soviet government were significantly strengthened, when the privatelyowned economic structure was practically liquidated, a strong apparatus of administrative suppression of dissent was created, the new government began active anti-religious work and atheistic propaganda. For this, in 1928, the Union of Militant Atheists was created in Uzbekistan, publishing the magazine Khudosizlar (Atheists). And in the early 30s, open repressions began against the Muslim clergy and the old national intelligentsia, which led to their almost complete destruction.

\section{REFERENCES}

1. Urazaev Sh.Z. VI Lenin and the construction of Soviet statehood in Turkestan. Tashkent, 1967, p. 60

2. Ibid.

3. Malashenko A.V. Islamic revival in modern Russia. M., 1998, p. 48

4. Bennigsen A. Muslims in the USSR. Paris, 1983, pp. 22-23

5. Central State Archives of the Republic of Uzbekistan. Form 39. Op. 1. D.11. L.5

6. Communist Party of Turkestan in the resolutions of congresses and conferences. - Tashkent, 1988.S. 47

7. Turkestan communist, 1919 , July 16

8. CPT in resolutions ... p.86

9. Bennigsen A. Op. Cit. P.23

10. Vishnevsky A. How it was done in Central Asia // Science and religion. 1990. No. 3. P.44

11. Ikramov A. On the clergy at school // Selected works in 3 volumes. Vol. 1. Tashkent: Uzbekistan, 1972, p. 280

12. Saidbaev T.S. Islam and Society. The experience of historical and sociological research. Moscow, 1978, p. 134

13. Malashenko A.V. Decree. op. P.49

14. TsGA RUz. F.Z-17. Op. 1. D.306. L. 98

15. Saidbaev T.S. Decree. op .. p. 146

16. Babadzhanov B.M., Muminov A.K., Olcott M.B. Muhammadjan Hindustani (1892- 
1989) and the religious environment of

his era. // Vostok, 2004, №5, p.48

17. CSA RUz. F R-904. Op. 1. D.32. L.25

18. Ibid. L. 19

19. Ikramov A. Fav. works. T.Sh. Tashkent, 1974 -- p. 301

20. Communist Party of Uzbekistan in resolutions and decisions of congresses and plenums of the Central Committee. T.P. Tashkent: Uzbekistan, 1987, p. 301,303 